\title{
DESA WISATA HIDROPONIK SEBAGAI UPAYA PEMBERDAYAAN MASYARAKAT DESA SIDOMULYO KECAMATAN ANGGANA KABUPATEN KUTAI KARTANEGARA
}

\author{
Hendra Saputra $^{1}$, Rudianto ${ }^{1}$, Dwikie Setiawan ${ }^{1}$, Rudy Agung Nugroho ${ }^{1 *}$ \\ ${ }^{1}$ Jurusan Biologi, Fakultas Matematika dan Ilmu Pengetahuan Alam, Universitas Mulawarman, Samarinda, \\ Indonesia \\ *Penulis korespodensi : rudyagung.nugroho@fmipa.unmul.ac.id
}

\begin{abstract}
Abstrak
Dalam pembangunan desa di era modern saat ini, desa dituntut untuk mampu berperan aktif, mandiri serta dapat memenuhi kebutuhannya dengan kemampuan sendiri. Hal ini tertuang dalam UU No. 06 tahun 2014 Tentang Desa. Program pengabdian masyarakat ini bertujuan untuk memberdayakan masyarakat Desa Sidomulyo Kecamatan Anggana Kabupaten Kutai Kartanegara sebagai upaya meningkatkan perekonomian desa melalui Desa wisata hidroponik. Program ini memiliki luaran: terbentuknya keterampilan masyarakat Desa Sidomulyo bercocok tanam secara hidroponik; terbentuknya pusat tanaman hidroponik di Desa Sidomulyo; terbentuk kelompok-kelompok kecil dalam setiap Rukun Tetangga (RT) untuk bercocok tanam secara hidroponik; adanya kunjungan pendidikan ke Desa Wisata Hidroponik dari siswa-siswi Sekolah Dasar (SD), Sekolah Menengah Pertama (SMP) dan Sekolah Menengah Atas (SMA) yang berlokasi di Kecamatan Anggana. Metode pelaksanaan yang digunakan meliputi dua hal besar: tahap persiapan dan tahap inti. Hasil pelaksanaan yang telah dicapai sebagai berikut: seluruh sesi dalam tahap persiapan dan program inti dari sosialisasi, peresmian, kegiatan inti serta project desain berhasil diraih sesuai target. Indikatornya adalah: masyarakat sekitar sering berkunjung ke pusat hidroponik pada sore hari dan membeli peralatan serta sayuran hidroponik serta belajar teknik menanam hidroponik. Hasil positf lain adalah dipublikasikannya program ini dalam media masa Samarinda Pos, Repository Website Unmul dan terbentuknya kelompok-kelompok kecil hidroponik.
\end{abstract}

Kata kunci: Hidroponik, Desa Wisata, Desa Sidomulyo, Pemberdayaan masyarakat

\begin{abstract}
Hydroponic tourism village as an effort of community empowerment of Sidomulyo village, Anggana district, Kutai Kartanegara regency. In the modern era, a village is required to be able to play an active, independent and meet their needs with their own ability as stated in the Indonesian Law Act. No. 06 2014. Therefore, current community service program aimed to empower the community of Sidomulyo Village, Anggana Subdistrict Kutai Kartanegara Regency as an effort to improve the economy sector through Hydroponics tourism village. This program has an outcome: the formation of community skills Sidomulyo hydroponic Village; the establishment of hydroponic center in Sidomulyo Village; small groups formed in each neighboring group for hydroponic cultivation; the presence of educational visits to the Hydroponics Tourism Village from elementary school, Junior High School and Senior High School located in Kecamatan Anggana. The method of implementation used: the preparation and core stage. The results were: all sessions in the preparation and core program of inauguration have been succesfully implemented, socialization, core activities and design projects have also been achieved as expected. Community were interested to visit the hydroponic center in the afternoon, bought hydroponic equipment, vegetables and learn hydroponic planting techniques. Other positive results were publication in daily newspapers Samarinda Pos, Repository Unmul and the formation of small groups of hydroponics.
\end{abstract}

Keywords: Hydroponic plantation, tourism village, Sidomulyo village, Community Service

\section{PENDAHULUAN}

\subsection{Analisis situasi}

Secara geografis desa Sidomulyo, Kecamatan Anggana terletak pada posisi 117o13'-117o36' BT dan 0o24 LS0o54'LS (Gambar 1). Kecamatan Anggana sendiri mempunyai luas sekitar $1.798,80 \mathrm{~km} 2$ dengan jumlah penduduk mencapai 43.338 jiwa yang tersebar di 8 desa, sedangkan kepadatan penduduk Anggana adalah 26 penduduk $/ \mathrm{km} 2$. Pusat pemerintahan Kecamatan Anggana berada di desa Sungai Mariam dan desa-desa lain di wilayah Anggana adalah: Anggana, Handil 
terusan, Kutai Lama, Muara Pantuan, Sepatin, Tani Baru dan Sidomulyo (Monograph, 2017).
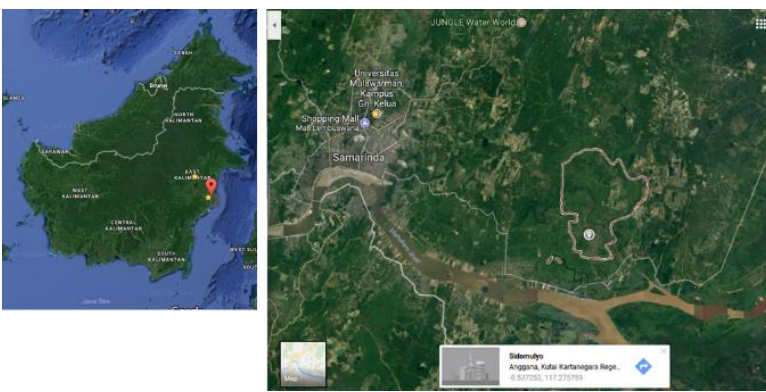

Gambar 1. Letak geografis desa Sidomulyo, kecamatan Anggana, kabupaten Kutai Kertanegara, Kalimantan Timur.

Desa Sidomulyo adalah salah satu desa yang berada di Kecamatan Anggana Kabupaten Kutai Kartanegara. Untuk mencapai desa ini dibutuhkan waktu 45 menit sampai 1 jam (dari Samarinda) dengan menggunakan kendaraan motor atau mobil. Sarana untuk menuju lokasi ini sudah memadai karena jalan sudah di semenisasi dan aspal. Desa ini terdiri dari 4 dusun dan 16 rusun tangga (RT) dan memiliki fasilitas pendidikan yaitu dua Sekolah Dasar (SD) yang berlokasi di pusat Desa Sidomulyo, satu Pendidikan Anak Usia Dini (PAUD) dan dua Taman Kanak-kanak (TK). Desa Sidomulyo memiliki daya tarik untuk di kunjungi karena memiliki Jembatan Gantung yang usianya sudah lama dan anak Sungai Mahakam yang airnya berwarna hijau. Desa ini juga sering dikunjungi oleh Komunitas Motor Trail karena terdapat lokasi yang cocok untuk off road. Selain itu, suasana pedesaan yang asri juga merupakan salah satu daya tarik pengunjung untuk berkunjung ke desa ini.

Masyarakat Desa Sidomulyo sebagian besar berprofesi sebagai petani, nelayan dan pegawai swasta, sedangkan ibu-ibu di desa ini sebagian besar tidak bekerja atau sebagai ibu rumah tangga. Kegiatan ibu rumah tangga di desa ini selain sebagai rumah tangga juga sebagian dari ibu-ibu bergabung sebagai anggota PKK. Kegiatan yang dilakukan ibu-ibu PKK ini lebih banyak berfokus kepada kegiatan bercocok tanam seperti bercocok tanam tanaman obat dan budidaya jamur. Namun, kegiatan tersebut hanya dilakukan sebagai sambilan dan pengisi waktu luang. Sementara itu, kegiatan bercocok tanaman dengan model hidroponik masih belum dilakukan karena kendala teknis meskipun potensi lahan kosong sangat luas. Optimalisasi lahan merupakan salah satu usaha ketahanan pangan, sehingga fungsi lahan kosong berubah menjadi lahan yang produktif. Lahan kosong diharapkan mampu memenuhi kebutuhan sayuran pada tingkat rumah tangga sehingga tingkat konsumsi sayuran di Indonesia bisa meningkat. Untuk kondisi seperti ini maka bentuk pertanian di lahan kosong yang dapat ditawarkan adalah dengan memanfaatkan kemajuan teknologi seperti hidroponik dan berbagai bentuk pertanian vertikal (Krisnohadi et al., 2017; Roidah, 2015)
Hidroponik sendiri berasal dari bahasa Yunani yaitu "hydro" yang berarti air dan "ponos" yang mempunyai arti daya atau tenaga kerja. Dengan demikian, menanam dengan sistem hidroponik berarti cara tanam dengan media air atau tenaga kerja air. Hidroponik merupakan budidaya tanaman tanpa media tanah. Hidroponik berarti budidaya tanaman yang menggunakan air dan tanpa tanah sebagai media tanam (soilless). Keuntungan teknik menanam secara hidroponik yaitu tidak terlalu membutuhkan tempat yang luas. Syasiatnya adalah kebutuhan nutrisi bagi tanaman terpenuhi dan dengan sinar mataharinya cukup (Alhadi, 2016; Siregar, 2018). Kegiatan hidroponik ini diangkat dalam program pengabdian kepada masyarakat karena Konsumsi sayuran di Indonesia masih rendah yaitu 40,35 kg/kapita per tahun. Hal tersebut tergolong lebih rendah dari masyarakat Vietnam dan Singapura yang mencapai lebih dari 100 $\mathrm{kg} /$ tahun (Latifah et al., 2014).

\subsection{Permasalahan}

Dalam menjalankan kegiatan tanam hidroponik tersebut ibu-ibu masih mengalami beberapa kendala seperti minininya informasi terhadap cara bercocok tanam yang baik, hal tersebut juga disebabkan untuk mendapatkan informasi tersebut harus pergi ke luar desa dan membutuhkan biaya yang cukup besar. Hal tersebut berimbas pada perkembangan kegiatan dari ibu-ibu untuk bisa bercocok tanam dan mengikuti perkembangan ilmu becocok tanam khususnya hidroponik. Hal ini tentu akan menghambat perkembangan dalam pembangunan Desa Sidomulyo yang memiliki potensi besar untuk dikembangkan. Oleh karena itu dibutuhkan suatu cara untuk dapat membangun desa ini menjadi desa yang berkembang sebagaimana yang dimuat di dalam UU. No. 06 tahun 2014 Tentang Desa, desa membawa angin segar untuk pemerintah desa saat ini.

\section{TARGET DAN LUARAN}

Program pengabdian kepada masyarakat ini bertujuan untuk memberdayakan masyarakat desa Sidomulyo yang mempunyai potensi wilayah untk dikembangkan dan minat masyarakat untuk berkembang secara ekonomi. Adapun tujuan dicapai dengan adanya adanya program desa wisata hidroponik yang ditawarkan dan merupakan salah satu cara yang tepat sesuai dengan potensi yang ada dan permasalahan yang ada di Desa Sidomulyo. Terdapat beberapa kegiatan yang dilakukan dalam program desa wisata yang dapat membangun desa ini yaitu: 1) pelatihan keterampilan bercocok tanam secara hidroponik kepada masyarakat Desa Sidomulyo terutama ibu-ibu rumah tangga. Pelatihan keterampilan bercocok tanam ini dapat menjadi modal ibu-ibu untuk dapat bercocok tanam secara hidroponik dengan beragam jenis tanaman. 2) Mempromosikan desa wisata hidroponik ini dengan memberikan edukasi kepada siswa-siswi sekolah dasar mengenai bercocok tanam hidroponik kepada sekolahsekolah yang ada di Kecamatan Anggana untuk dapat melakukan wisata pendidikan ke desa wisata 
hidnoponik. 3) Pembangunan pusat hidroponik serta membentuk kelompok-kelompok hidroponik di setiap RT. Kegiatan-kegiatan yang dilaksanakan pada dasarnya bertujuan agar masyarakat secara umum memiliki kemampuan bercocok tanam hidroponik yang dapat memberikan daya tarik bagi desa sebagai tempat wisata dan masyarakat dapat menjadi wirausaha hidroponik yang akan meningkatkan perekonomian desa.

\section{METODE PELAKSANAAN}

Kegiatan pengabdian kepada masyarakat ini dilakukan melalui dua tahapan yaitu, persiapan dan pelaksanaan program inti. Tahapan persiapan meliputi beberapa tahap yaitu:

a) Tinjauan Ulang Masyarakat Sasaran

Kegiatan pertama yang dilakukan dalam tahap persiapan merupakan tinjauan ulang masyarakat sasaran. Kegiatan yang dilakukan ini bertujuan untuk mengetahui keadaan terakhir dan kondisi desa Sidomulyo Kecamatan Anggana Kabupaten Kutai Kartanegara. Kegiatan ini dilakukan dengan cara melakukan kunjungan ke lokasi.

\section{b) Koordinasi}

Setelah mengetahui gambaran dan masyarakat tersebut didapat dari hasil tinjau ulang, maka dilakukan rumusan-rumusan strategi yang lebih akurat terkait pelaksanaan kegiatan. Kegiatan ini dilakukan dengan berkoordinasi antara tim pengabdian pada masyarakat dan aparatur desa terkait dalam rangka mendapatkan arahan yang lebih baik dipelaksanaan program.

c) Koordinasi Dengan Kepala Desa Sidomulyo

Selanjutnya kegiatan dilanjutkan dengan pembuatan kesepahaman antara tim dengan sasaran. Dalam hal ini yang akan dilakukan adalah berupa penjelasan mengenai detail dari program dan seluruh rangkaian kegiatan yang akan dilaksanakan kepada pihak desa Sidomulyo yang diwakili kepala desa. Hal ini dilakukan sebagai bentuk komunikasi antara tim dengan pihak sasaran sehingga dalam pelaksanaan program nanti bisa berjalan dengan baik. Komunikasi dan koordinasi ini juga dilakukan untuk mendapatkan gambaran waktu-waktu yang tepat dalam setiap rangkaian kegiatan yang akan dilakukan dengan mempertimbangkan saran-saran dan rekomendasi dari pihak terkait.

d) Penyusunan Rangkaian Kegiatan

Selanjutnya langkah yang akan dilakukan adalah menyusun detail rangkaian kegiatan yang akan dilaksanakan. Tim yang telah mendapatkan saran dan arahan dari pihak kepala desa, terkait jadwal kegiatan di desa Sidomulyo kemudian akan menyusun detail dan rangkaian dalam pelaksanaan kegiatan. Penyusunan rangkaian kegiatan ini dilakukan dengan mempertimbangkan rekomendasi dan pihak kepala desa. Hal ini dilakukan agar terjadi kesepahaman serta kelancaran dalam proses pelaksanaan kegiatan program.

e) Persiapan Alat Dan Bahan

Pada kegiatan ini, tim yang telah menyusun detail rangkaian kegiatan kemudian akan melakukan persiapan alat dan bahan yang dibutuhkan selama pelaksanaan program. Alat dan bahan yang telah didapatkan kemudian dibentuk dan dijadikan sebagai media penunjang dalam pelaksanaan kegiatan.

f) Sukarelawan

Rekruitmen sukarelawan merupakan kegiatan yang dilakukan dengan membuka kesempatan bagi berbagai pihak yang ingin terlibat dalam pelaksanaan program. Tim akan membuka kesempatan ini utamanya kepada mahasiswa di lingkungan kampus Fakultas Matematika dan Ilmu Pengetahuan Alam (FMIPA) Universitas Mulawarman yang ingin berpartisipasi dalam kegiatan. Publikasi terkait rekruitmen sukarelawan akan dilakukan melalui pemberitahuan lisan oleh tim yang kemudian akan diteruskan dari mulut ke mulut sehingga dapat diketahui oleh banyak orang. Hal ini dilakukan agar tim mendapatkan tenaga dan pikiran dalam pelaksanaan kegiatan.

Sementara untuk program inti juga meliputi beberapa tahapan yaitu:

a) Peresmian Kegiatan

Peresmian kegiatan merupakan bentuk pembukaan dalam serangkaian kegiatan yang akan dilakukan dalam program. Dalam kegiatan peresmian program ini, akan dilaksanakan pembukaan secara resmi oleh pihak kepala desa dengan maksud membuka serangkaian kegiatan yang akan dijalankan. Dalam peresmian program ini digunakan sebagai ajang mengenalkan program kepada masyarakat yang akan dituju. Selain itu, dalam kegiatan ini juga akan dijadikan sebagai bentuk pendekatan antara tim dengan masyarakat, sehingga nantinya akan terjalin komunikasi dan kerja sama yang baik selama pelaksanaan program.

b) Sosialisasi

Pada tahap sosialisasi ini yang akan dilakukan adalah pengenalan mengenai kegiatan, Iangsung kepada masyarakat desa sidomulyo. Kegiatan sosialisasi akan dilakukan di luar kantor kepala desa. Pada tahap ini, masyarakat akan diberikan gambaran dan penjelasan mengenai kegiatan secara rinci. Hal ini bertujuan untuk mengenalkan secara langsung kepada masyarakat tentang bagaimana bercocok tanam tanpa menggunakan media tanah seperti pada umumnya.

c) Kegiatan Inti

Kegiatan inti dan program ini akan mengacu pada pembelajaran mengenai cara praktis dalam pembuatan hidroponik serta memberi bimbingan disela-sela pembuatan hidroponik mengenai 
pentingnya pola hidup sehat dengan mengkonsumsi makanan-makanan dan hasil bercocok tanam dengan cara hidroponik dan membuat satu pusat hidroponik dimana masyarakat nantinya jika mengalami kesusahan dalam menanam tanaman dapat datang ke pusat hidroponik tersebut dan sekaligus di pusat hidroponik tersebut menyediakan nutrisi dan bibit untuk masyarakat yang membutuhkan.

d) Project Design

Di akhir program, ada dua kegiatan yang dilaksanakan yaitu mendatangkan kunjungan dan sekolah-sekolah ke desa wisata dan lomba. Kunjungan dan sekolah-sekolah ini merupakan tanggapan dari sekolah pada saat tim pengabdian mempromosikan desa wisata hidroponik Sidomulyo. Sementara itu, dalam lomba, Tim pelaksana menilai RT yang paling berhasil dalam menanam tanaman dengan cara hidroponik, waktu yang diberikan untuk merealisasikan project design adalah selama dua minggu.

\section{HASIL DAN PEMBAHASAN}

Kegiatan pengabdian pada masyarakat ini telah dilaksanakan di Desa Sidomulyo, Kecamatan Anggana, Kabupaten Kutai Kartanegara. Berikut ini diuraikan hasil dari program pengabdian kepada masyarakat tersebut. Dalam tahap persiapan telah dilakukan beberapa tahap, yaitu:

a) Tinjauan Ulang Masyarakat Sasaran

Sebelum program inti dilakukan telah diadakan interaksi langsung dengan masyarakat, dan beberapa persiapan di tahap awal dilakukan. Pada tanggal 04 April 2017 telah dilaksanakan tinjauan lokasi di daerah tersebut untuk menentukan lokasi pembuatan pusat hidroponik. Setelah dilakukan konfirmasi kepada aparatur desa dan meninjau lokasi, pada tanggal 09 April 2017 telah dilakukan kunjungan kepada pemilik rumah yang akan dijadikan sebagai lokasi pusat hidroponik yang bertujuan untuk meminta kesediaan pemilik rumah untuk bekerjasama membangun pusat hidroponik di lahan pemilik rumah. Pemilik rumah yang memiliki lahan yang digunakan sebagai tempat pembuatan pusat hidroponik yang beralamatkan RT. 13 kediaman Ibu Dahlia (Gambar 2).

\section{b) Koordinasi}

Setelah dilakukan tinjauan ulang masyarakat sasaran dan didapatkan hasil berupa gambaran umum pelaksanaan lokasi pembentukan pusat hidroponik serta beberapa kendala yang mungkin terjadi saat pelaksanaan program, kemudian telah dilakukan diskusi dengan tim pengabdian masyarakat dan aparatur terkait untuk mendapatkan solusi dan rumusan strategi yang tepat saat menjalankan program.

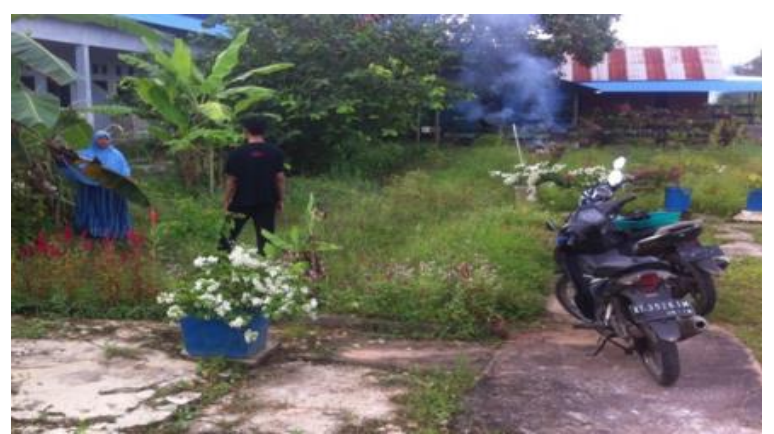

Gambar 2. Peninjauan lokasi tempat pembuatan pusat hidroponik di lahan masyarakat Sidomulyo

c) Koordinasi dengan pengusaha hidroponik Selain berdiskusi dengan tim pengabdian dan aparatur, diskusi juga dilakukan dengan pengusaha hidroponik di Samarinda yang telah memiliki banyak pengalaman dalam usaha hidroponik Ada 2 tempat yang dijadikan sebagai tempat diskusi yaitu di Teras Hidroponik yang beralamat di JI. Padat Karya gang Karya Mandiri 6 No.34, Sempaja Utara dan di Graha Indah Farm yang beralamat di JI. Graha Indah, Blok R No.6, Air Putih, Samarinda Ulu (Gambar 3).
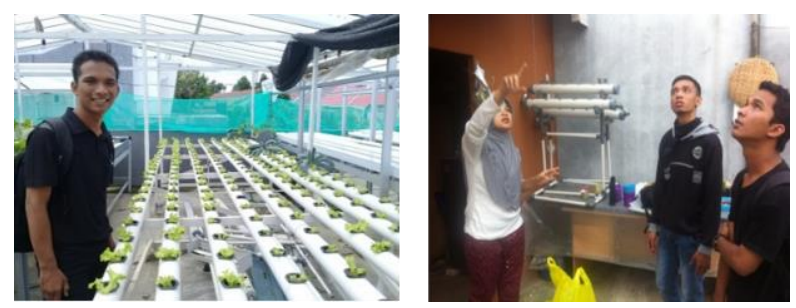

Gambar 3. Kunjungan dan konsultasi hidroponik di teras hidroponik (Gambar kiri) dan Graha Indah Farm (Gambar kanan) di kota Samarinda.

d) Koordinasi dengan Kepala Desa Sidomulyo Untuk dapat mengeksekusi program inti, maka pada tanggal 04 April 2017 telah dilakukan kunjungan ke Kantor Desa Sidomulyo dengan tujuan untuk mengkonfirmasi kegiatan yang akan dilaksanakan di Desa Sidomulyo. Pada kunjungan tersebut, Kepala Desa dan aparatur desa sangat mendukung kegiatan yang akan dilaksanakan (Gambar 4).

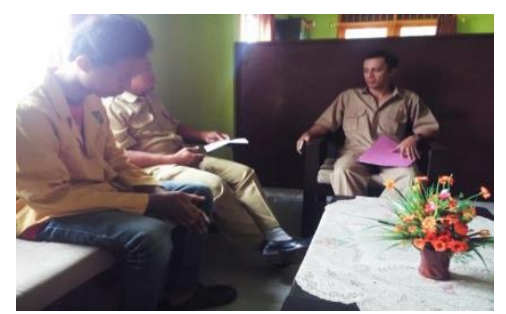

Gambar 4. Kordinasi pembukaan pusat desa wisata hidroponik desa Sidomulyo ke kepala aparatur desa Sidomulyo

e) Penyusunan rangkaian kegiatan

Rangkaian kegiatan disusun berdasarkan hasil tinjauan ulang serta hasil diskusi dengan dosen 
pembimibing. Pada proses penyusunan rangkaian kegiatan ini didapatkan urutan rangkaian kegiatan yang disusun berdasarkan lama waktu kerja setiap program kerja. Sehingga didapatkan rangkaian kegiatan yaitu pembangunan pusat hidroponik, sosialisasi dan pelatihan, peresmian desa wisata hidroponik dan pusat hidroponik, project design, kemudian dilanjutkan dengan pasca program berupa pemantauan secara berlanjut.

f) Persiapan alat dan bahan

Persiapan alat dan bahan untuk keperluan hidroponik dilakukan secara bertahap. Pembelian secara bertahap dilakukan untuk menghindari alat dan bahan yang berlebih. Pembelian alat dan bahan untuk keperluan pembangunan hidroponik dilakukan di pusat hidroponik di Samarinda yaitu di Teras Hidroponik dan Graha Indah Farm.

g) Perekrutan relawan

Telah dilakukan perekrutan relawan yang berasal dan Mahasiswa Jurusan Biologi FMIPA Unmul. Relawan yang direkrut berjumlah 42 orang. Relawan yang direkrut bertugas dalam membantu proses sosialisasi sayuran hidroponik dan desa wisata hidroponik ke beberapa Sekolah Dasar (SD) di Desa Sidomulyo.

Sementara, program inti yang telah dilakukan adalah sebagai berikut:

a) Peresmian Kegiatan

Kegiatan peresmian desa wisata hidroponik telah dilakukan pada hari selasa tanggal 6 Juni 2017 pada jam 10.00-12.00 WITA di desa Sidomulyo kediaman pekarangan rumah Ibu Dahlia RT 13 di samping pusat hidroponik. Peresmian kegiatan ini dihadiri oleh perwakilan kepala desa Sidomulyo dan ketua ibu-ibu PKK Sidomulyo serta beberapa masyarakat desa yang hadir dalam peresmian sekaligus pembukaan desa wisata hidroponik dan pusat hidroponik di Desa Sidomulyo. Dalam kegiatan ini secara resmi telah dibuka oleh perwakilan kepala desa dengan pemotongan pita secara simbolis (Gambar 5).

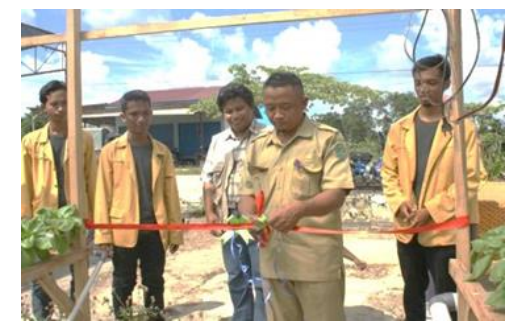

Gambar 5. Peresmian pusat hidroponik desa Sidomulyo dengan pemotongan pita secara simbolis oleh aparatur desa

\section{b) Sosialisasi}

Sosialisasi dilakukan pada masyarakat umum dan siswa-siswi Sekolah Dasar (SD) di Desa Sidomulyo. Sosialisasi yang dilakukan berupa cara bercocok tanam secara hidroponik, keuntungan dan hidroponik, peluang usaha hidroponik serta rencana menjadikan Desa Sidomulyo menjadi Desa Wisata Hidroponik. Pada tanggal 20 Mei 2017 telah dilakukan sosialisasi kepada siswa-siswi di Sekolah Dasar (SD) yang berada di Desa Sidomulyo yaitu SDN 008 Anggana dan SDN 009 Anggana (Gambar 6). Dalam sosialisasi ini siswa-siswi tersebut dibekali mengenai cara bercocok tanam hidroponik (sistem terapung) dan dikenalkan pusat hidroponik yang telah dibangun di Desa Sidomulyo sebagai lokasi wisata pendidikan agroforestri.

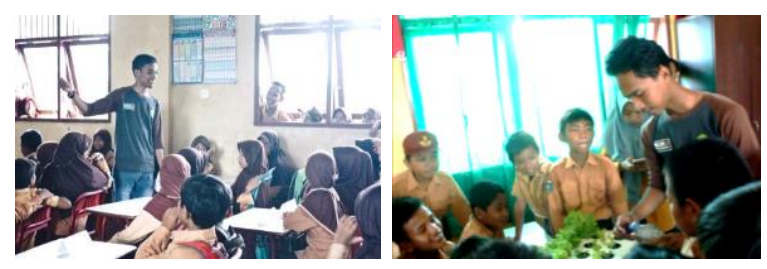

Gambar 6. Sosialisasi kepada siswa-siswi Sekolah Dasar (SD) Desa Sidomulyo

Setelah sosialisasi kepada siswa-siswi Sekolah Dasar (SD), pada tanggal 4 Juni 2017 dilakukan pula sosialisasi kepada masyarakat umum di Desa Sidomulyo dengan mendatangi masyarakat dan rumah ke rumah (Gambar 7). Sosialisasi yang dilakukan berupa pengenalan rencana menjadikan Desa Sidornulyo menjadi Desa Wisata Hidroponik dan cara bercocok tanam secara hidroponik dengan sistem terapung. Dan hasil sosialisasi ini didapatkan 6 rumah dan 3 RT di Desa Sidomulyo. Selain dan rumah ke rumah, sosialisasi kepada masyarakat umum juga dilakukan pada saat peresmian desa wisata hidroponik mengenai peluang bisnis hidroponik serta mengajak masyarakat untuk dapat mengembangkan desa wisata hidroponik yang telah dibangun. Sosialisasi ini dilanjutkan dengan pemberian perlengkapan hidroponik dengan sistem sumbu kepada perwakilan 3 RT dan satu kelompok PKK dengan harapan dapat menjadi pelopor Desa Wisata Hidroponik.

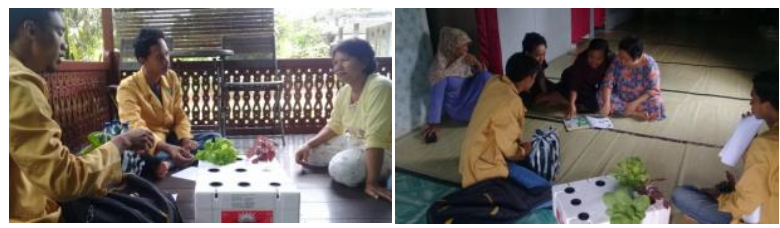

Gambar 7. Sosialisasi hidroponik ke masyarakat

c) Kegiatan Inti

Dalam kegiatan ini telah dilakukan bersamaan dengan kegiatan sosialisasi. Sosialisasi ini yang telah dilakukan berupa sosialisasi pembuatan hidroponik kepada para siswa SD yang berada di Desa Sidomulyo yaitu SDN 008 Anggana dan SDN 009 Anggana sebagai langkah awal pengenalan hidroponik secara dini. Selain itu sosialisasi pembukaan desa wisata pusat hidroponik dilakukan ke rumah-rumah masyarakat serta mempromosikan ke masyarakat tersedianya alat dan nutrisi yang 
dapat dibeli di pusat hiroponik desa Sidomulyo (Gambar 8).
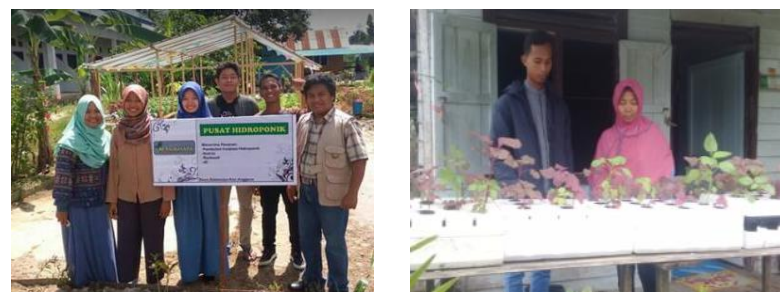

Gambar 8. Sosialisasi dan mempromosikan ke masyarakat tentang pusat hidroponik yang menyediakan peralatan dan sayuran hidroponik

Di pusat hidroponik, model yang digunakan adalah sistem Net film Technique (NFT) dengan pipa peralon. Instalasi hidroponik ini dibuat permanen dan membutuhkan biaya yang relatif besar, namun kelebihannya dapat bertahan sampai belasan tahun (Surtinah and Nizar, 2017). Untuk instalasi di rumah penduduk menggunakan sistem sumbu yang relatif lebih murah karena menggunakan boks styroform bekas.

\section{d) Project Design}

Dalam melaksanakan project design ini ada 2 pembagian yaitu melakukan lomba pada tiap RT dan wisata pendidikan agroforestri berupa kunjungan dan siswa-siswi sekolah dasar ke pusat hidroponik. Wisata pendidikan agroforesti ini sudah tercapai dengan terbentuknya pusat hidroponik sebagai sarana edukasi bagi siswa SD dan dengan kunjungan dan siswa-siswi SD ke pusat hidroponik, hal ini menjadi langkah awal yang bagus untuk menarik siswa-siswa untuk berkunjung ke pusat hidroponik (Gambar 9).
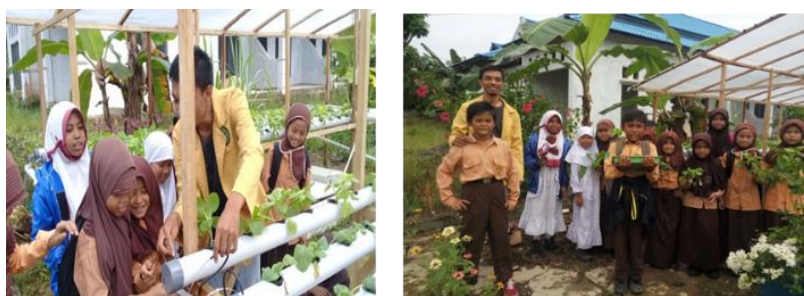

Gambar 9. Kunjungan siswa SD ke pusat hidroponik sebagai desa wisata pendidikan siswa-siswi SD Sidomulyo

Kegiatan lomba tiap RT bertujuan untuk memacu semangat masyarakat untuk mendapatkan hasil yang terbaik dan menjadi percontohan bagi masyarakat lain. Kegiatan ini diawali dengan membagikan satu set perlengkapan hidroponik yang telah disiapkan kepada perwakilan setiap RT, penilaian dilakukan setelah kurang lebih 3 minggu penanaman. Dalam kegiatan ini yang berhasil sebagai RT terbaik adalah RT 12. Penghargaan untuk beberapa nominasi pemenang berupa starter kit hidroponik (Gambar 10).
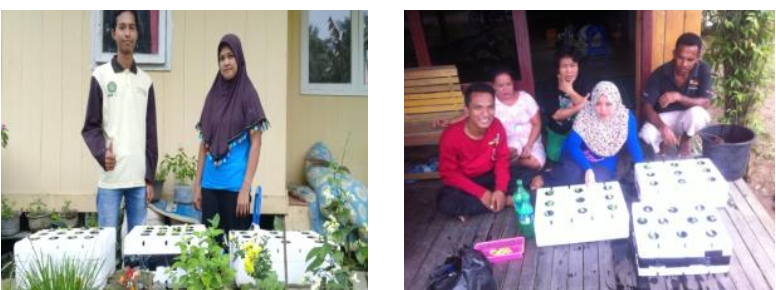

Gambar 10. Lomba project desain

e) Potensi hasil kegiatan

Kegiatan pengabdian kepada masyarakat yang telah berhasil dilaksanakan dan terus berjalan, mempunyai berbagai potensi untuk dikembangkan lebih lanjut. Penjelasan mengenai potensi hasil dari pelaksanaan program ini lebih lanjut dijelaskan pada Tabel 1 berikut:

Tabel 1. Potensi kegiatan lanjutan dari program pengabdian kepada masyarakat

\begin{tabular}{|c|c|c|}
\hline No & $\begin{array}{l}\text { Ruang } \\
\text { lingkup } \\
\text { Potensi }\end{array}$ & Keterangan \\
\hline 1 & Artikel Ilmiah & $\begin{array}{l}\text { Program yang terlaksana sangat } \\
\text { memungkinkan untuk diliput dan } \\
\text { dipublikasikan oleh jurnalis yang } \\
\text { lebih masif sehingga informasi } \\
\text { pengabdian kepada masyarakat } \\
\text { dapat diakses secara luas }\end{array}$ \\
\hline 2 & Sosial & $\begin{array}{l}\text { Adanya desa wisata ini diharapkan } \\
\text { banyak wisatawan yang datang } \\
\text { sehingga masyarakat desa mampu } \\
\text { bersosialisasi terhadap wisatawan }\end{array}$ \\
\hline 3 & Ekonomi & $\begin{array}{l}\text { Panen dapat secara luas } \\
\text { didistribusikan ke kota, restoran } \\
\text { dan supermarket }\end{array}$ \\
\hline 4 & Pendidikan & $\begin{array}{l}\text { Desa wisata ini dapat di jadikan } \\
\text { tempat pembelajaran agroforestri } \\
\text { sekaligus wisata pendidikan }\end{array}$ \\
\hline 5 & Usaha & $\begin{array}{l}\text { Dengan adanya desa wisata ini } \\
\text { dapat juga dijadikan usaha } \\
\text { sampingan yang lain sehingga } \\
\text { pendapatan masyarakat pun } \\
\text { bertambah }\end{array}$ \\
\hline
\end{tabular}

\section{KESIMPULAN}

Kegiatan program pengabdian kepada masyarakat ini telah berlangsung dengan baik, dimulai dengan kegiatan persiapan hingga terlaksananya program inti. Capaian kegiatan program pengabdian kepada masyarakat ini adalah terbentuknya kelompokkelompok kecil dalam setiap Rukun Tetangga (RT) untuk bercocok tanam secara hidroponik; adanya kunjungan pendidikan ke Desa Wisata Hidroponik dari siswa-siswi Sekolah Dasar (SD), Sekolah Menengah Pertama (SMP,) dan Sekolah Menengah Atas (SMA) yang berlokasi di Kecamatan Anggana.

Hasil yang dicapai lainnya adalah, adanya pusat desa wisata hidroponik dan penjualan alat serta bahan hidroponik. Masyarakat sekitar sering berkunjung ke pusat hidroponik pada sore hari dan membeli peralatan serta sayuran hidroponik serta belajar teknik menanam hidroponik. 


\section{UCAPAN TERIMA KASIH}

Tim Pengabdian kepada Masyarakat mengucapkan terima kasih kepada Kemenristekdikti atas sponsor dana hibah dalam kegiatan ini melalui surat penugasan no: 547/ B3. 1/KM/2017. Tim juga mengucapkan terima kasih kepada Jurusan Biologi Fakultas Matematika dan Ilmu Pengetahuan Alam, Universitas Mulawarman, Samarinda yang telah mendukung terlaksananya kegiatan ini. Tak lupa kepada, masyarakat dan aparatur desa Sidomulyo, Anggana, Kutai Kertanegara, yang telah mendukung terlaksananya kegiatan ini

\section{DAFTAR PUSTAKA}

Alhadi, D.G.D. (2016). Pengaruh Penggunaan Beberapa Warna Lampu Neon terhadap Pertumbuhan Tanaman Kailan (Brassica oleraceae) pada Sistem Hidroponik Indoor. Jurnal Teknik Pertanian Lampung 5(1): 13-24.

Krisnohadi, A., Gunawan, J., and Yvi, U.S. (2017). Penerapan Pertanian Vertikultur dan Pembuatan Pupuk Organik Cair Berbasis Limbah Ikan pada Ibu-Ibu Nelayan di Dusun Nirwana, Kecamatan Sei Kakap. Jurnal Dinamika Pengabdian (JDP) 3(1): 89-96.

Latifah, E., Boga, K., and Maryono, J. (2014). Pengenalan Model Kebun Sayur Sekolah untuk Peningkatan Konsumsi Sayuran bagi Para Siswa di Kediri-Jawa Timur. Agriekonomika 3(1): 34-44.

Monograph. 2017. Monograph Kecamatan Anggana. http://kabupaten.kutaikartanegara.com/index.ph p?kategori=Kabupaten\&menu=Gambaran_Um um Accessed 10-09- 2017.

Roidah, I. S. (2015). Pemanfaatan Lahan dengan Menggunakan Sistem Hidroponik. Jurnal Bonorowo 1(2): 43-49.

Siregar, M. (2018). Respon Pemberian Nutrisi Abmix pada Sistem Tanam Hidroponik Terhadap Pertumbuhan dan Produksi Tanaman Sawi (Brassica Juncea). Jasa Padi 2(2): 18-24. 